\title{
3-ハロインドレニンの化学
}

池 田 正 澄* ・田 村 恭 光*

\section{The Chemistry of 3-Haloindolenines.}

Masazumi IKEDA * and Yasumitsu TAMURA*

3-Haloindolenines are capable of reacting in a number of ways to lead to a variety of products, depending on the structure of substrates and experimental conditions. This review evaluates critically the usefulness of this reactive intermediates in the indole chemistry.

\section{1.はじめに}

3-ハロインドレニン 1 は 1956 年にインドールアルカロ イドの分野で活性な中間体としてデビューして以来 ${ }^{1) * *}$, インドールアルカロイドの合成や変換反応にしばしば利 用されている他，簡単なインドール誘導体への置換基導 入，あるいは環変換反応にも応用され，また，本稿では 直接触孔ないが，インドールの八ロゲン化の際の中間体 として仮定される ${ }^{2)}$ など，インドールの化学の中で重要 な役割をはたしている。ところで，3-ハロインドレニン は極めて多様な反応性を示し，その上同じ化合物でも反 応条件の変化で異なる成績体を与えたり，また逆に同じ 反応条件であっても少しの構造の違いから異なった反応 をすることがあったりしてなかなか興味深い。本稿では 主に 2,3-ジ置換 3-ハロインドレニンについてその合 成化学的な有用性を紹介し，併せて反応性と基質の構造 や反応条件などとの関係についてもできるだけ触れるよ らに努めた。とはいってもそれぞれの反応機構について 詳しく検討されているわけではなく，いつも明快に割切 れるとは限らないことを断りしておかなくてはならな い。本論に入る前に 3-ハロインドレニンの合成法とそ の一般的な性質について簡単に触れておきたい。

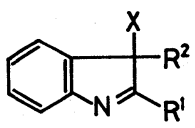

$1 \mathrm{X}=\mathrm{Cl}, \mathrm{Br}, \mathrm{I}$

* 大阪大学薬学部

* Faculty of Pharmaceutical Sciences, Osaka University

\section{2. 合 成 法}

3-クロロインドレニンの合成に用いられる最も一般的 な方法は不活性溶媒, たとえばベンゼンや塩化メチレン 中，インドールとトリェチルアミンの存在下 $t$ ブチルハ イポクロライト $(t-\mathrm{BuOCl})$ を反応させるもので収率は 一般に高い ${ }^{1,3)}$ 。その他のクロル化剂として次亜塩素酸

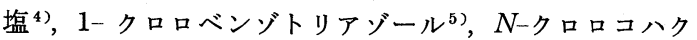
酸イミド $\left.(\mathrm{NCS})^{6}\right) ， N$-クロロアセタミド6) なども用い られる。3-ブロモインドレニンは一般にインドールと $N-$ ブロモコハク酸イミド (NBS) との反応によって得られ る $^{7,8)}$ 。3- 3 ウドインドレニンはインドールとアジ化ヨ ウ素 $\left(\mathrm{IN}_{3}\right)$ との反応の際の反応中間体として考えられて いる ${ }^{9)}$ が単離された例はない。

3-ハロインドレニンの生成機構に関してハロゲン化が

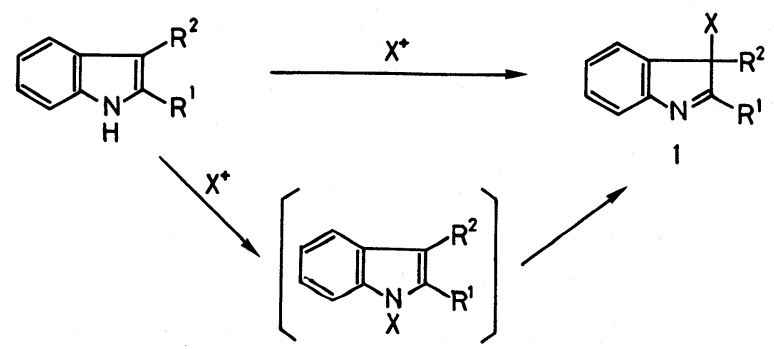

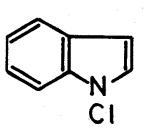

2

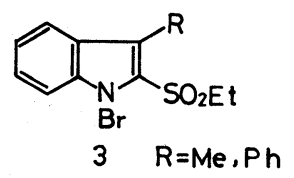

**当初, 誤まった構造が提出されていたがその後3-ハ口 インドレニン構造に訂正された ${ }^{3)}$ 。 
直接 3 位で起っているのか, 最初に 1 位に起って後 3 位 に転位するのかという問題で最近興味ある報告がみられ る。P.G.Gassman ら ${ }^{4)}$ はアニリンの塩素化がまず窒素 上で起る事実を基に後者の可能性を示唆したが，これを 十分証明することはできなかった。後に M.De Rosa ${ }^{10)}$ はインドールをペンタン中次亜塩素酸ナトリウムと低温 で反応させ 1-クロロインドール 2 の生成を確認, そし てこれが3-クロロインドールに変換することをみとめた。 最近, 日野ら ${ }^{8)}$ は1-ブロモインドール誘導体 3 を安定に 取り出すことに成功し，さらにこれが3-゙ロモインドレ ニンに転位することを報告している。これらの実験によ って必らずしも問題が解決したわけではないが興味ある 実験結果といえる。

\section{3. 性質}

一般に3-ハロインドレニンは室温で不安定であるが安 定な結晶として単離できる場合もある。インドールアル カロイドから導かれるクロロインドレニンは一般に比較 的安定な結晶として単離されている。この場合エピマー の存在が考えられるが，実際混合物として得られること が多い。3-ハロインドレニンが不安定な場合にはその純 度をヨウドメトリー法で定量できる4 ${ }^{4}$ 。

3-ハロインドレニンは次のようなスペクトルの特性吸 収をもっている。IRスペクトルではインドール特有の強 い $\mathrm{NH}$ の吸収が消失し， $\mathrm{C}=\mathrm{N}$ に基つく吸収が 1,500 $1,600 \mathrm{~cm}^{-1}$ 付近に現われ，また UV スペクトルではイ ンドレニン特有の二つの吸収極大（一般に短波長測の吸 収が長波長測の吸収より強度が大きい）を示す。NMR スペクトルも構造の推定にしばしば有効で，たとえば 3 位メチル基がインドールの場合より約 $0.6 \mathrm{ppm}$ 高磁場側 にシフトする。

\section{4. 合成化学的応用}

3-ハロインドレニン 1 の $\mathrm{C}-\mathrm{X}$ 結合が開裂する時, 形 式的には八ロゲン $(\mathrm{X})$ が陽イオン $\left(\mathrm{X}^{+}\right)$, 陰イオン $\left(\mathrm{X}^{-}\right)$ あるいはラジカル $\left(\mathrm{X}^{*}\right)$ として切れる可能性が考えられ る。実際その全てのタイプの反応がみとめられているけ れども大部分の反応は八ロゲンが陰イオンとして抜けて いくタイプに属することになるので開裂の仕方によって 分類することは適当とは思われない。むしろ3-ハロイン ドレニンの反応を成績体の種類によって分類した方が実 際的であると思われるのでこの分類に従って以下に詳し

く述べていくことにする。

4.1. 2-アルコキシインドレニンの生成３-ハロイ ンドレニンはアルコール性アルカリと還流すると2-アル
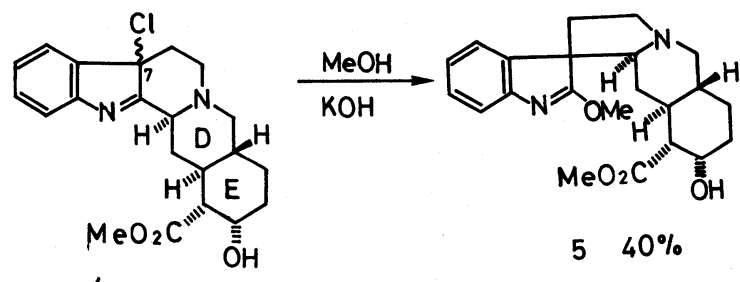

$540 \%$

4
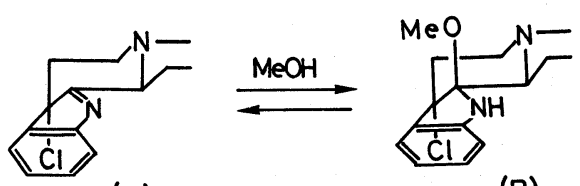

(A)

(B)

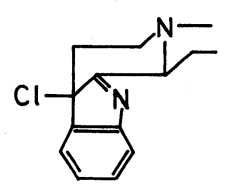

(C)
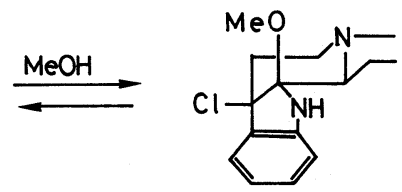

(D)

コキシインドレニンを生成する。この反応は 1962 年 $\mathrm{N}$. Finch と W.I. Taylor ${ }^{3)}$ がョヒンビンから導かれるクロ ロインドレニン 4 の 7 位エピマーの混合物 (1: 1)を メタノール性アルカリと還流することによって2-メトキ シインドレニン 5 に転位することを見出したことにはじ まる。 5 は酸で容易に加水分解されて相当するオキシイ ンドールに変換される。

この反応を他のヨヒンビン型アルカロイドに適用する と $\mathrm{D} / \mathrm{E}$ trans 配置をもつアルカロイド（たとえばアジ マリシンなど）は転位体を与えるのに対し，D/E cis 配 置をもつアルカロイド（たとえばデゼルピジン, イソデ ゼルピジンメチルエステルなど) では一種類のクロロ インドレニンが生成し，これはメタノール性アルカリ条 件下全く転位しない。これを説明するために Taylor ら は $\mathrm{B} ， \mathrm{D}$ の中間体を想定し，この中転位は塩素原子と転 位基である $\mathrm{C}-\mathrm{C}$ 結合が anti-coplanar の配置をとって いるDからのみ起るのであろうと考えている。そうだと すると $\mathrm{D} / \mathrm{E}$ trans のアルカロイドでは $\mathrm{A} ， \mathrm{C}$ 二つのクロ ロインドレニンをほぼ $1 ： 1$ の混合物で与え, その中 C のみが転位することになり，また D/E cisのアルカロイ

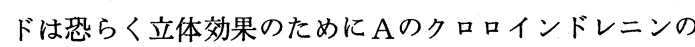
みを与え，全く転位しないということになる。（ただし， クロロインドレニンの立体化学は決定されているわけではな い)。ところがその後 L. J. Dolby ら ${ }^{11)}$ はクロロインド レニン 6 のエピマーを分離しそれぞれをメタノール性水 酸化カリウムで処理するといずれからも対応する2-メト

*この転位に関して坂井進一郎, 有合化, 30,434 (1972) も参照。 
<smiles>Cl[C@]12CCN3CCCC[C@H]3C1=Nc1ccccc12</smiles>

62

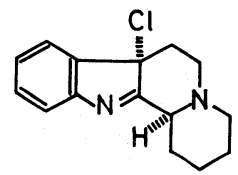

$6 b$

キシインドレニンを生成することを述べており，話はや やこしい。

クロロインドレニン 7 についてアルカリの種類（水酸 化ナトリウムとナトリウムメトキシド）と温度の影響が 詳しく調べられている ${ }^{12}$ 。 この場合置換反応 (4.4. で述 べる）と転位反応の競争反応となっていて一般に水酸化 ナトリウムを使って温度が高い程 $\left(-10{ }^{\circ} \mathrm{C} \sim 65{ }^{\circ} \mathrm{C}\right)$ 転 位体 8 の比率が増大している。Wagner-Meerwein 型の 転位機構が新たに提案されている。この機構は Dolbyら の結果を説明するには都合がよい。もう一つ Favorskii 転位型の中間体 9 を経る機構が考えられる。この考え方 は魅力的ではあるが中間体の歪の問題で可能性としては そしいであろう。

この反応は最近 $10 ， 11$ にも応用され ${ }^{13)}$, さらにはア<smiles>ClC12CCCCC1=Nc1ccccc12</smiles>

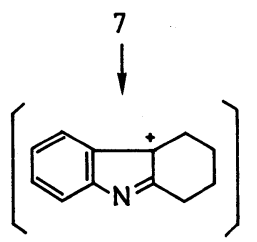<smiles>CCCC1(C(=O)OC)C2CCCC1c1ccccc12</smiles>

9<smiles>[R]C1CCCN2CC[C@](Cl)(C1)C1=Nc3ccccc3[C@H]12</smiles>

$12 a-c$

a, $R=H(=6)$

b. $R=E t$

c. $\mathrm{R}=\mathrm{Ac}$

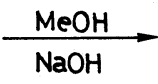

$\longrightarrow$<smiles>[R]NCC1=Nc2ccccc2C1(Cl)Cl</smiles>

$10 \mathrm{R}=\mathrm{Me}$ $11 \mathrm{R}=\mathrm{CH}_{2} \mathrm{Ph}$<smiles>[R]C1(CC)CCC(=O)N2CC[C@@]3(Cl)C(=Nc4ccccc43)C21</smiles>

$13 a-c$

a. $\mathrm{R}=\mathrm{H}$

b. $R=E t$

c, $\mathrm{R}=\left(\mathrm{CH}_{2}\right)_{2} \mathrm{CO}_{2} \mathrm{Et}$

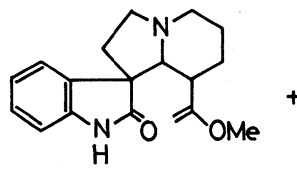

14
スピドスペルマアルカロイドの合成を目的として次のよ うなインドロキノリチジン誘導体 $12^{14)}, 13^{15)}$ にも本 反応の応用が試みられている。

$12 \mathrm{a},=6$ は前述のように転位が進行するけれども $12 \mathrm{~b}$ では反応せず，12c の場合には予期に反してオキシイン ドール 14 と 15 が得られる。12c の異常性は図に示した ような隣接基関与を考えて説明されている ${ }^{14)}$ 。

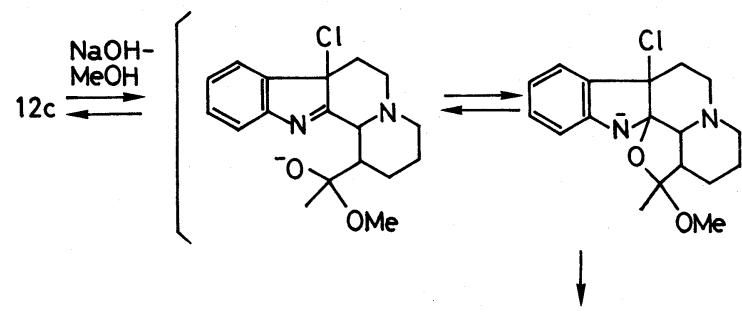<smiles>COC(=Nc1ccccc1)C12CCN3CCCC(C(C)(OC)OC)C1C32</smiles>

13a の場合は期待される 16 はわずか $16 \%$ で他に 17 (25\%)，18a (14\%) が副生する。一方 13b，c は 18b， c のみを与える ${ }^{15)}$ 。1 位に大きな基があるとメトキシイ オンの攻撃が妨げられるのであろう。

最近, タリウムエトキシド (TlOEt) とベンゼン中還 流することによっても本転位の進行することが報告され ている ${ }^{16,17)}$<smiles>CCC1CCC(=O)N2CCC(C)(/C(=N/c3ccccc3)OC)C12</smiles>

16<smiles>CCC1=C2c3[nH]c4ccccc4c3CCN2C(=O)CC1</smiles>

17<smiles>[R]C(CC)(CCCOC)C1=NCCc2c1[nH]c1ccccc21</smiles>

18 a, $\mathrm{R}=\mathrm{H} ; \mathrm{b}, \mathrm{R}=\mathrm{Et} ; \mathrm{c}, \mathrm{R}=\left(\mathrm{CH}_{2}\right)_{2} \mathrm{CO}_{2} \mathrm{Me}$ 
4.2. オキシインドールの生成３-ハロインドレニ ンを酸で処理すると一般にオキシインドールを生成する。 1962 年 H. Zinnes と J. Shavel, Jr. ${ }^{18)}$ はヨヒンビンのク ロロインドレニン 4 を酢酸で $\mathrm{pH} 6$ に調整した水性メ夕 ノール中還流すると直接一行程でオキシインドール19の 生成することを明らかにした*。

このオキシインドール生成反応は種々のヨヒンビン型 アルカロイドに適用されている ${ }^{18,19) 。}$

19 の生成に関して Zinnes ら ${ }^{18)}$ は次の二つの機構を提 案している。

4

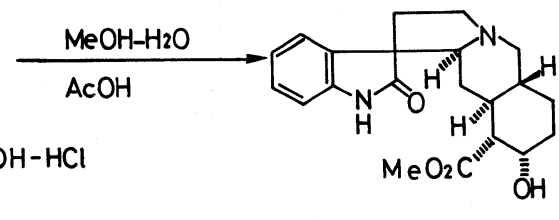

19

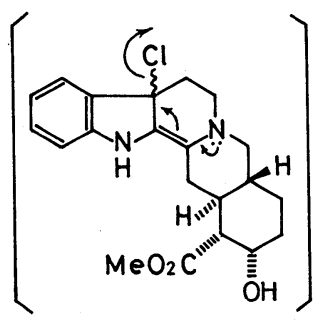<smiles>COC(=O)[C@H]1[C@H](O)CC[C@@H]2C[N+]3=C(Cc4c3[nH]c3ccccc43)C[C@H]21</smiles>

20

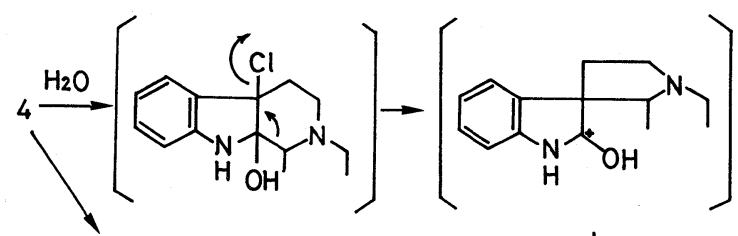<smiles>CCCCCCCC</smiles><smiles>[3H][3H]</smiles>
19

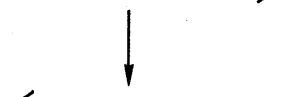

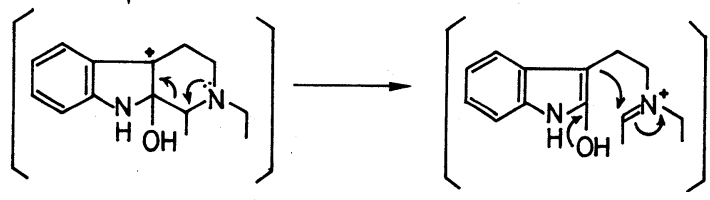

その後多くのインドール誘導体について検討された結 果, 表 1 に示したょうにいろいろな 2 位置換基の転位が

*この反応は 4 を無水塩化水素で処理すると極めて容易にデヒドロヨ ヒンビン 20 を与えるのと対照的である ${ }^{1)} 。 20$ は二重結合の移動 後 (4.5. 参照), $\mathrm{Nb}$ の関与があって生成するものと考えられている。

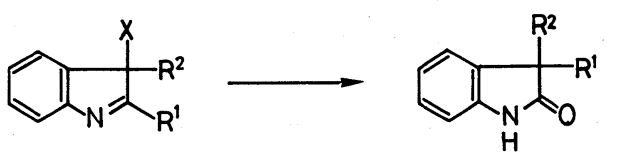

Table 1. Preparation of Oxindoles a)

\begin{tabular}{|c|c|c|c|c|c|}
\hline $\mathrm{R}^{1}$ & $\mathrm{R}^{2}$ & $\mathrm{X}$ & Conditions & $\begin{array}{l}\text { Yield } \\
(\%)\end{array}$ & Ref. \\
\hline $\mathrm{Ph}$ & $\mathrm{Ph}$ & $\mathrm{Cl}$ & $\mathrm{AcOH}$, r.t. & quant. & 20 \\
\hline SEt & $\mathrm{Me}$ & $\mathrm{Br}$ & $\mathrm{EtOH}-\mathrm{HCl}$, r.t. & 81 & 8 \\
\hline $\mathrm{SO}_{2} \mathrm{Et}$ & $\mathrm{Me}$ & $\mathrm{Br}$ & " & 79 & 8 \\
\hline $\mathrm{SO}_{2} \mathrm{Et}$ & $\mathrm{Ph}$ & $\mathrm{Br}$ & " & 94 & 8 \\
\hline \multirow{2}{*}{\multicolumn{2}{|c|}{$\begin{array}{l}-\mathrm{O}\left(\mathrm{CH}_{2}\right)_{2}-\mathrm{CH}_{2-}^{-} \\
-\mathrm{S}\left(\mathrm{CH}_{2}\right)_{2}-\mathrm{CH}_{2-}^{-}\end{array}$}} & $\mathrm{Cl}$ & " & 89 & 21 \\
\hline & & $\mathrm{Cl}$ & " & 56 & 21 \\
\hline CON & $\mathrm{Me}$ & $\mathrm{Cl}$ & $\mathrm{EtOH}$, reflux & 75 & 22 \\
\hline
\end{tabular}

a) For further examples, see ref. 22 .

みとめられた ${ }^{8,20 \sim 22)}$ 。例外的に 2 位アセチル基, カルボ キシル基は本条件下で脱離する ${ }^{22)}$ 。

A. Walser ら ${ }^{22)}$ は Zinnes らの機構とは少し異なった 機構を提唱している。

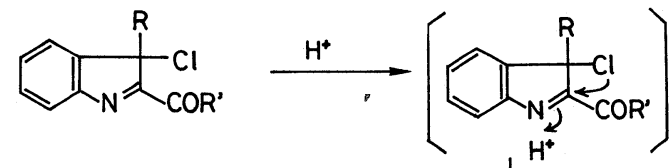

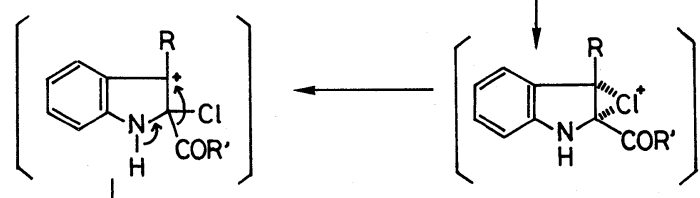<smiles>[R7]C(=O)C1([R])C(=O)Nc2ccccc21</smiles>

その他, ラクタム $13 \mathrm{a}-\mathrm{c}$ は稀酢酸中 $60^{\circ} \mathrm{C}$ に加温す るとオキシインドール 21a-c に転位する ${ }^{15)}$ 。 21 c はビン カジフォルミン，アスピドスペルミジンの全合成中間体<smiles>[R]C[C@]1(CC)CCC(=O)N2CC[C@@]3(Cl)C(=Nc4ccccc43)[C@]21CC(C)=O</smiles>
13 21
a. $\mathrm{R}=\mathrm{H}$
b. $R=E t$
c, $\mathrm{R}=\left(\mathrm{CH}_{2}\right)_{2} \mathrm{CO}_{2} \mathrm{Me}$
$22 \%+17(21 \%)$
$35 \%+12.5 \%{ }^{a}$
$36 \%+12 \%$

a) diastereoisomer 
として知られている ${ }^{23)}$ 。

4.3. 2-アルキリデンインドリンの生成クロロイ ンドレニン７はマロン酸エステルのタリウム塩とベンゼ ン中還流することによって少量のテトラヒドロカルバゾ

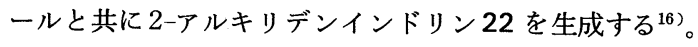
この時ナトリウム塩を使ったのでは 22 は得られず, 原 料回収かテトラヒドロカルバゾールにもどってしまう。 また, 他の活性メチレン化合物, たとえばアセト酢酸エ チル, アセチルアセトン, ジメドン, ベンゾイル酢酸エ チル, シアノ酢酸エチル, マロノニトリル, ニトロメタ ンのタリウム塩ではテトラヒドロカルバゾール，ヒドロ キシインドレニン 23 (最初の三例) などを生成するの みで 22 に相当する化合物は得られていない。アセト酢 酸エチルのタリウム塩の場合にはその他に 24 と 25を少 量副生する。22 の生成の反応機構の詳細は不明であるが, 形式的にはオキシインドールの生成と同じょうに考える

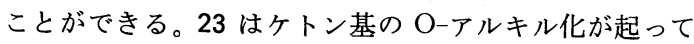
後加水分解して生成したものであろうと思われ, また24, 25 は C-アルキル化が起ったものであろうと考えられて いる。<smiles>ClC12CCCCC1=Nc1ccccc12</smiles>

7<smiles>OC12CCCCC1=Nc1ccccc12</smiles>

23<smiles>CCOC(=O)C(C(C)=O)=C1c2ccccc2NC12CCCC2</smiles>

24
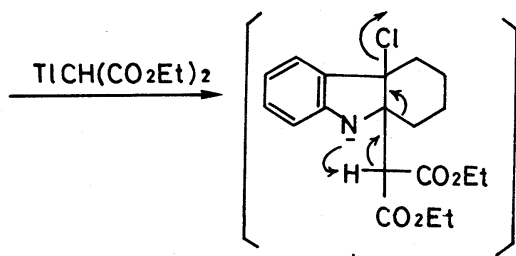

$\downarrow$

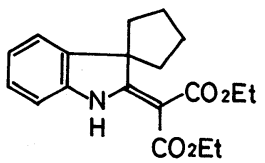

$22 \quad 47 \%$

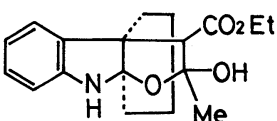

25
この反応をクロロインドレニン 10 に応用すると興味 あることにインドロアゼピン誘導体 26a が得られる ${ }^{17)}$ 。 この反応は最初上と同じ反応が起るがさらにフラグメン テーションを起こしてインモニウム体を与え，これが再 閉環して 26aを与えたものと考えられている。11から得 られた $26 \mathrm{~b}$ は，このあと数行程を経てビンカジフォルミ ンに導かれている。

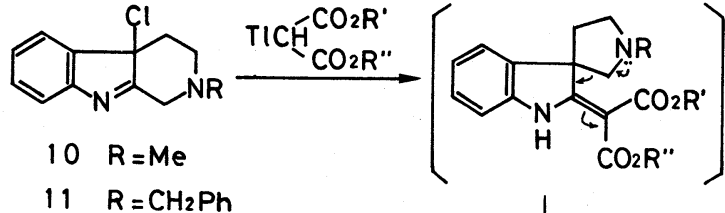

$11 \mathrm{R}=\mathrm{CH}_{2} \mathrm{Ph}$<smiles>[3H][3H]</smiles>

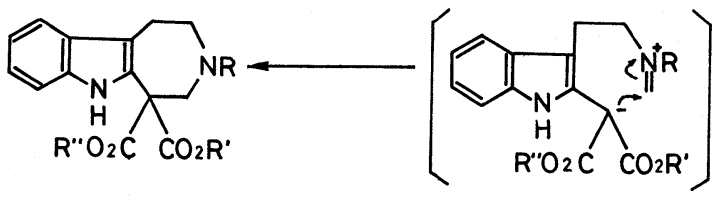

26a $R=M e, R^{\prime}=R^{\prime \prime}=E t$

26b $R=\mathrm{CH}_{2} \mathrm{Ph}, \mathrm{R}^{\prime}=t-\mathrm{Bu}, \mathrm{R}^{\prime \prime}=\mathrm{Me}$

4.4. 3-置換インドレニンの生成３-ハロインドレ ニンに求核試薬を反応させるとしばしば 3 位で直接置換 反応を起こし，3-置換インドレニンが生成する。この反 応の成否は基質の構造, 反応条件, あるいは求核剂の種 類などによって決まるようで例は多くないがこれらの要 因について考察してみる。

アルコキシルやアセトキシル基の置換反応は銀イオン の存在下で行ならとよいようである。たとえば熱的に不 安定な 3-クロロインドレニン 27 にナトリウムメトキ

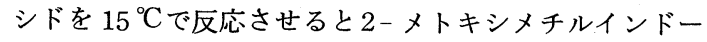
ル 29 を生成するが, トリフルオロ酢酸銀の存在下 -10 ${ }^{\circ} \mathrm{C}$ でメタノール中攪汼すると $94 \%$ の収率で 3-メトキシ インドレニン 28 を生成する ${ }^{4)}$ 。また, クロロインドレ ニン 30 のアセトキシル化を酢酸中酢酸ナトリウムで行 な5と反応は遅く ( 72 時間以上), 31 ( $52 \%$ ) 以外に 2,3-ジフェニルオキシインドール $(9 \%), 2,3-$ ジフェ ニルインドール $(3 \%)$ を副生する。しかし酢酸銀を用 いると 2 時間で定量的に 31 のみを与える ${ }^{20) 。 ~}$<smiles>CC1=Nc2ccccc2C1(C)Cl</smiles>

27
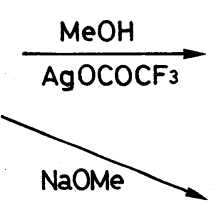

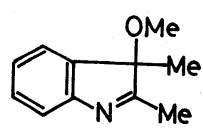

28<smiles>COCc1[nH]c2ccccc2c1C</smiles>

29<smiles>ClC1(c2ccccc2)C(c2ccccc2)=Nc2ccccc21</smiles>

30<smiles>CC(=O)OC1(c2ccccc2)C(c2ccccc2)=Nc2ccccc21</smiles>

31 
クロロインドレニン 7 は $0{ }^{\circ} \mathrm{C}$ でメタノール中ナトリウ ムメトキシドと反応させると $88 \%$ の収率で 32 を与え るが，メタノール中水酸化ナトリウムと還流すると4.1. で述べた 2-メトキシインドレニン 8 を $82 \%$ で与える。 32 と 8 の生成比は塩基と温度によって左右され, 温度 が高くなるに従って $\left(-10^{\circ} \sim 60^{\circ} \mathrm{C}\right)$ 転位成績体 8 の 生成が増大する ${ }^{12)}$ 。7はまた塩化メチレン中アジ化ナト リウムと反応させると $86 \%$ の収率で 33を与えるが，溶 媒として酶酸を用いると 34 を生成する ${ }^{20) 。 ~}$<smiles>ClC12CCCCC1=Nc1ccccc12</smiles>

7<smiles>N#CC1CCCc2c1[nH]c1ccccc21</smiles>

34
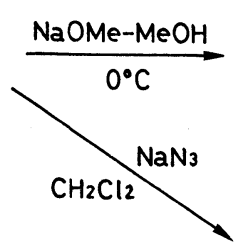

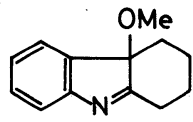

32

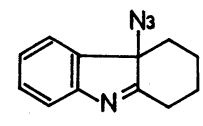

33
一見まとまりのないような話であるが，これはここに あげた 3-クロロインドレニン 27，30，7 の反応条件下 での安定性を反映しているのであって, たとえば 27 は - $25^{\circ} \mathrm{C}$ 以下では安定であるが, 温度を上げていくと( $\left.25^{\circ} \rightarrow 15^{\circ} \mathrm{C}\right)$ 二重結合の異性化 (29の生成と関係 ; 4.5 . 参照) (Gassman は他の可能性も示唆している)を起す 4)。それに対して 7 は中性付近では比較的安定である (しかし, 酢酸中では二重結合の異性化が起り易い)。勿 論, 30 ではこのような可能性はない。

30 は酢酸中 $\mathrm{N}_{3}^{-}$や ${ }^{-} \mathrm{OAc}$ との反応で 3 位での求核置 換反応によって対応する 3 位置換インドレニンを与える のに対して, $\mathrm{I}^{-}, \mathrm{Ph}_{3} \mathrm{P}, \mathrm{PhSH}, \mathrm{Br}^{-}, \mathrm{SCN}^{-}$の上うな求 核剤との反応では炭素よりも塩素原子を攻撃し, 元の 2 , 3-ジフェニルインドールを生成する (4.6。参照)。 $\mathrm{Br}^{-}$ と $\mathrm{SCN}^{-}$の場合には $\mathrm{BrCl}$ または $\mathrm{ClSCN}$ (またはこれに 準ずるもの）が生成し，これがインドールを親電子的に 攻撃してそれぞれ 6-ブロモおよび 6-チオシアナトーイン

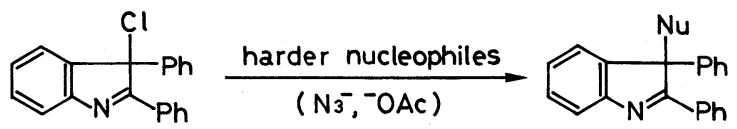

30

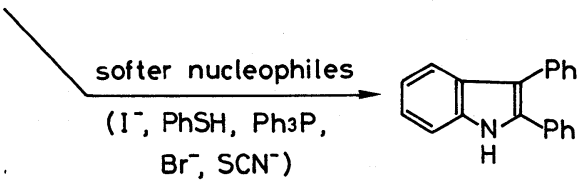

ドールを生成する (4.8. 参照) ${ }^{20)}$ 。このような求核剤に よる反応性の違いは HSAB の原理 ${ }^{24)}$ を用いて説明でき, より硬い求核凨 ( ${ }^{-} \mathrm{OAc}$ や $\mathrm{N}_{3}^{-}$) は硬い 3 位炭素を攻撃し 置換反応をするが，より軟かい求核阂 $\left(\mathrm{I}^{-}, \mathrm{PhSH}, \mathrm{Ph}_{3} \mathrm{P}\right.$, $\left.\mathrm{Br}^{-},-\mathrm{SCN}\right)$ は軟かい塩素原子を攻撃しインドールに戻 ってしまう。

最後にアジド基は3-クロローまたはブロモーインドレニ ンに対してアジ化ナトリウムを酢酸中反応させる以外に， インドールに直接アジ化ヨウ素またはアジ化臭素を反応 させても 3 位に導入することができる ${ }^{9,25)}$ 。この反応は 3-ハロインドレニンを経て進行しているものと考えられ る。

ここに得られた3-アジドインドレニンはジメチルホル ムアミド中加熱することによってキノキサリン，キナゾ リンに環扡大寸る ${ }^{25)}$ 。

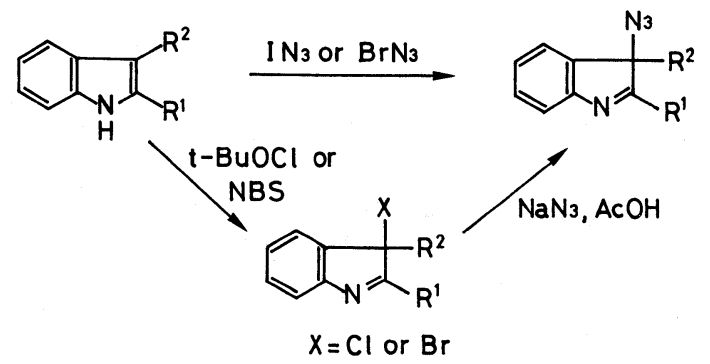

Table 2 Preparation of 3-Azidoindolenines

\begin{tabular}{l|l|c|c}
\hline \multirow{2}{*}{$\mathrm{R}^{1}$} & \multirow{2}{*}{$\mathrm{R}^{2}$} & \multicolumn{2}{|c}{ Yield (\%) } \\
\cline { 3 - 4 } & & By IN $\mathrm{IN}_{3}$ & $\begin{array}{c}\text { via 3-Chloro- } \\
\text { indolenines }\end{array}$ \\
\hline $\mathrm{Ph}$ & $\mathrm{Ph}$ & $100(98)^{\mathrm{a}}$ & $100(100)^{\mathrm{b}}$ \\
$\mathrm{Ph}$ & $\mathrm{Me}$ & $100(98)^{\mathrm{a}}$ & $100(100)^{\mathrm{b}}$ \\
$\mathrm{CO}_{2} \mathrm{Et}$ & $\mathrm{Me}$ & 85 & 100 \\
$\mathrm{CO}_{2} \mathrm{Me}$ & $\mathrm{CO}_{2} \mathrm{Me}$ & n. r. & 74 \\
\hline
\end{tabular}

a) By $\mathrm{BrN}_{3}$. b) via 3-Bromoindolenines.

4.5. 2 位メチレン側鎖に置換基の導入 2 位にメ チルやメチレン基をもつインドールから誘導される3-ハ ロインドレニンでは 2 位のアルキル側鎖に置換基を導入 することが可能になる。この反応は特にインドールアル カロイドの合成, 変換反応などにしばしば用いられ 3-ハロ インドレニンの反応の中で最も重要な反応の一つである。 反応機構についていろいろ考えられるが Taylor ${ }^{26)}$ の提 唱している機構で説明するのが普通である。すなわち, ハロゲンが脱離する前にエナミン 35 に異性化後, 求核 剤が $\mathrm{SN} 1$ または $\mathrm{SN} 2^{\prime}$ 機構で置換すると考えるものであ る。 
<smiles>[R]CC(=Nc1ccccc1)C([R])([X])[X]</smiles>

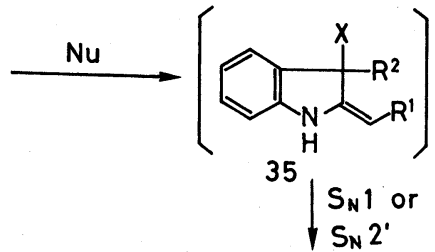<smiles>[R]c1c(C([R])[N+]#N)[nH]c2ccccc12</smiles>

従ってこの反応を成功させるには二重結合の異性化を 促進するような要因（基質の構造上の特性や反応条件な ど）を考慮する必要がある。たとえば，2,3-ジメチルイ ンドールの塩素化をー $78{ }^{\circ} \mathrm{C}$ で行ない，す早く $15{ }^{\circ} \mathrm{C}$ にあ たためてナトリウムメトキシドまたは酢酸タリウムと反 応させるとそれぞれ 36 と 37 が高収率で得られる。こ れは 27 が熱的に不安定で二重結合の異性化が起り易い ためであろう（Gassman は他の可能性も示唆している） 4)

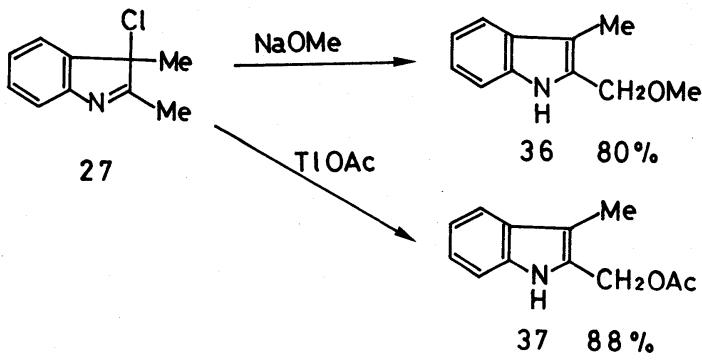

テトラヒドロカルバゾールから導かれたクロロインド レニン 7 は中性あるいは塩基性条件では二重結合の異性 化は起り難いようでメトキシル基やアセトキシル基を $\mathrm{C}_{1}$ 位に導入することには成功していない（前述のように $4 \mathrm{a}$ 位での置換または転位が起る) ${ }^{12)}$ 。しかし， $\mathrm{C}_{1}$ 位にエト キシカルボニル基を入れると容易に $\mathrm{C}_{1}$ 位にメトキシル 基や水酸基を入れることができるようになる ${ }^{27) 。 ~}$
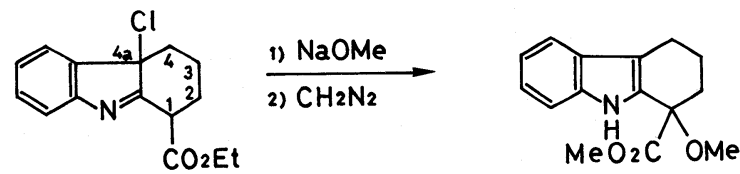

3-クロロインドレニン 39 に酢酸中アジ化ナトリウム

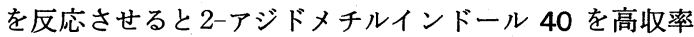
で得る ${ }^{28) 。 40 ~ は イ ン ト ゙ ー ル ~} 38$ にアジ化ヨウ素を反応 させることによっても直接得ることができる ${ }^{9,28)}$ 。 40 はこのあと二行程を経て $1,4-$ ベンジジアゼピン 41 に

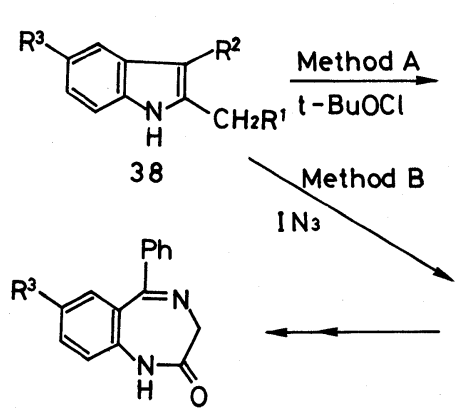

41

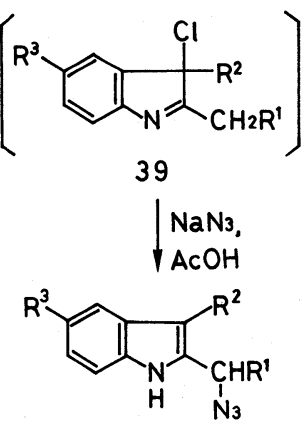

40

Table 3 Preparation of 2-Azidomethylindoles 40

\begin{tabular}{l|l|l|c|c}
\hline \multirow{2}{*}{$\mathrm{R}^{1}$} & \multirow{2}{*}{$\mathrm{R}^{2}$} & \multirow{2}{*}{$\mathrm{R}^{3}$} & \multicolumn{2}{|c}{ Yield (\%) } \\
\cline { 4 - 5 } & & & Method A & Method B \\
\hline $\mathrm{H}$ & $\mathrm{Me}$ & $\mathrm{H}$ & 93 & 94 \\
$\mathrm{Me}$ & $\mathrm{Me}$ & $\mathrm{H}$ & 94 & 91 \\
$\mathrm{H}$ & $\mathrm{Ph}$ & $\mathrm{H}$ & 72 & quant. \\
$\mathrm{H}$ & $\mathrm{Ph}$ & $\mathrm{Cl}$ & quant. & 93 \\
\multicolumn{2}{c}{$-\left(\mathrm{CH}_{2}\right)_{4^{-}}$} & $\mathrm{H}$ & 92 & 89 \\
\hline
\end{tabular}

導かれている ${ }^{28)}$

この反応は酢酸中では比較的容易に二重結合の異性化 が起るものと考えると Taylor の機構で説明が可能であ る。しかし 3-アジドインドレニン 33 が酢酸中比較的容 易に 34 に転位することから 39 が 3 位で $\mathrm{N}_{3}^{-}$と置換後, 二重結合の異性化， $[3,3]$ シグマトロピー転位を起すと いら可能性も考慮しておく必要があることを指摘してお きたい28)。

33

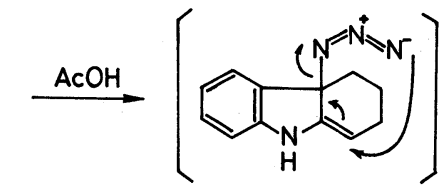

ヨヒンビン型アルカロイドでは前述のようにメタノー

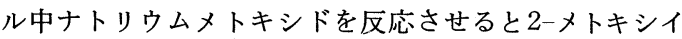
ンドレニン型化合物に転位する (4.1.)。ところが $\mathrm{Nb}$ を $N$-オキシドにすると種々の置換基を 3 位に導入でき るようになる $(42 \rightarrow 43 \text { 参照 })^{29)}$ 。これは恐らく 3 位水素 の酸性度が強くなって二重結合の異性化が促進される結 果であろう。

同様の効果が $\mathrm{Nb}$ を四級化することによっても期待さ れる。Dolby (11)はクロロインドレニン44の立体異性 体を分離し，それぞれを水性エタノール中酢酸ナトリウ ムと還流後，水酸化ナトリウムと処理すると 45 と 46 


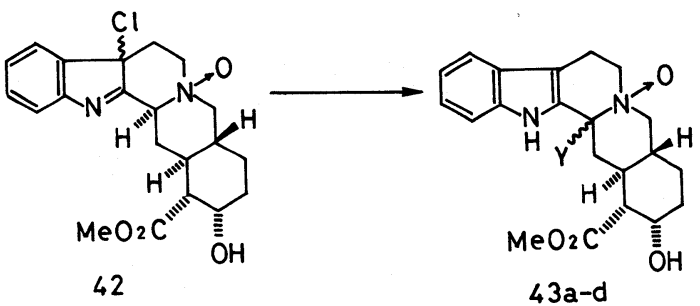

\begin{tabular}{ll} 
Conditions & $Y$ \\
\hline $\mathrm{KOH}-\mathrm{EtOH}$ & $\mathrm{OH}$ \\
$\mathrm{NaOMe}-\mathrm{MeOH}$ & $\mathrm{OMe}$ \\
$\mathrm{KCN}-\mathrm{MeOH}$ & $\mathrm{CN}$ \\
$\mathrm{KCH}\left(\mathrm{CO}_{2} \mathrm{Et}\right)_{2}-\mathrm{t}-\mathrm{BuOH}$ & $\mathrm{CH}\left(\mathrm{CO}_{2} \mathrm{Et}\right)_{2}$ \\
\hline
\end{tabular}

が得られることを報告している。 $\alpha$-クロロ-44と $\beta$-クロ ロ-44 とで 45 と 46 の生成比はそれ程変化はないが収 率は $\beta$-クロロ -44 の方がよい。生成機構として $\mathrm{A}, \mathrm{B}$ を 通る二つの機構が考えられている。<smiles></smiles>

44

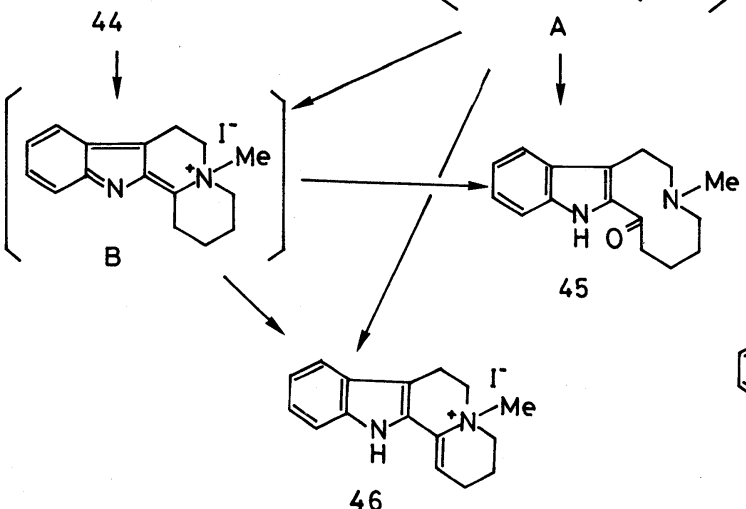

インドールの 2,3 位につく環が大きくなると二重結合 の移動は比較的容易になるようで，たとえば 47 に対し てシアノ基やメトキシル基を入れることができるように

*49 は次のような機構で生成したものと考えられている。

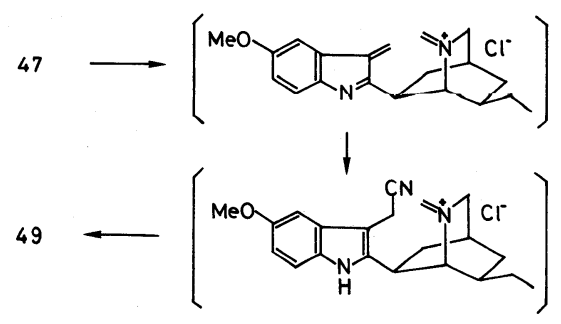

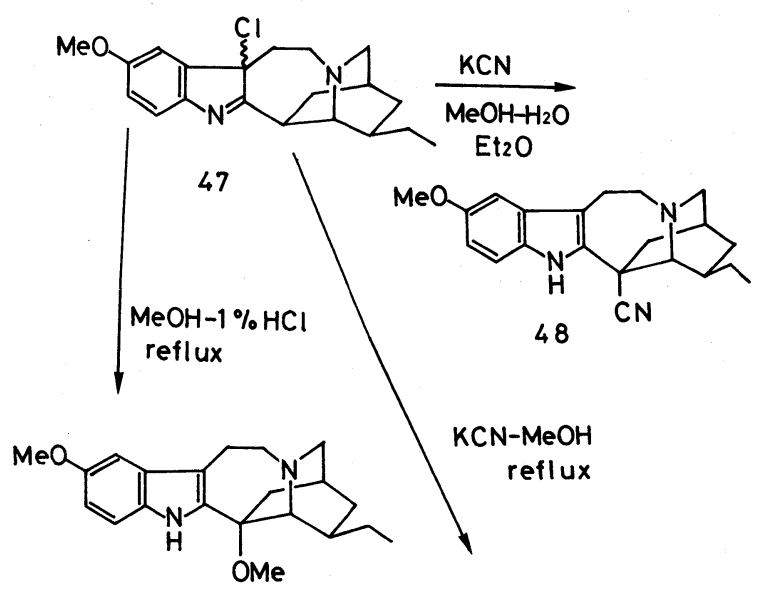

50

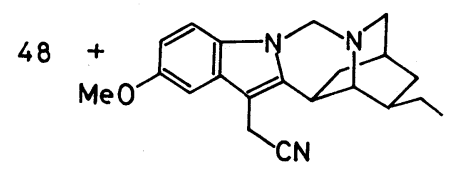

49

なる $\left.{ }^{30}\right) * ， 50$ の生成はこの条件下でたとえばョヒンビン から得られるクロロインドレニン 4 が2-メトキシインド レニンに転位するのと対照的である。これは 47 の塩素 原子が転位に不都合な配置 ( $\beta$ 配置) をとっているため だろらといわれている。

坂井ら ${ }^{31 ~ 33) ~}$ は 51 から誘導されるクロロインドレニ ン 52 をアルミナまたは酸で処理することによって2-ア シルインドール誘導体 53 に導く方法に展開している。

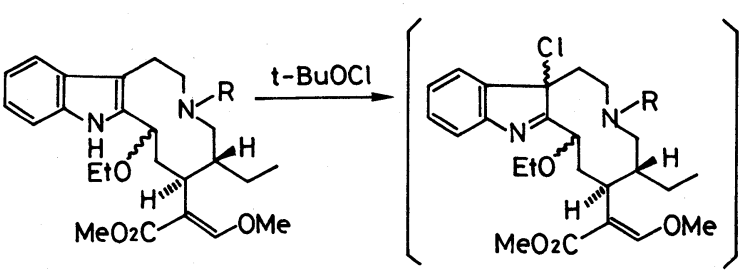

51

a, $\mathrm{R}=\mathrm{CN}$

b. $\mathrm{R}=\mathrm{CO}_{2} \mathrm{Et}$
$52 \mathrm{a}, \mathrm{b}$ $\mathrm{Al}_{2} \mathrm{O}_{3}$ or $\mathrm{H}^{+}$

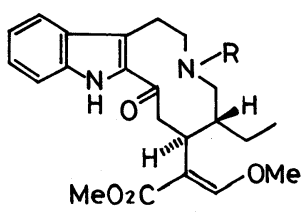

$53 a, b$
これらの反応の最も重要な応用は制ガン剤として有名 なビングラスチンなどのビスインドールアルカロイドの 
合成への応用であろう。これらのアルカロイドはビンド リンの芳香環がベルバナミンの $\mathrm{C}_{18}$ 位と結合している。 ビンドリンの活性なフェニル基の $\mathrm{C}_{15}$ 位を求核剤として 反応させればこの反応はビスインドールアルカロイドの 一般合成法を提供することになる。実際，N.Neussら ${ }^{34)}$ ははじめて $54(\mathrm{R}=\mathrm{H})$ とデアセチルビンドリンのヒド ラチドとのカップリングに成功し，その後 J.P. Kutney ら ${ }^{34 \mathrm{a})}$ はこの反応を $54\left(\mathrm{R}=\mathrm{CO}_{2} \mathrm{Me}, \mathrm{CN}\right.$ など $)$ に応用 して収率よくビス型アルカロイドの得られることを見出 した。しかし残念なことにこの反応は非天然型の $\mathrm{C}_{18}$ I ピマーを与えてしまう。これは恐らく $\alpha$ 側からの攻撃が 立体的な混み合いのために阻害された結果であろらと考 えられている34a)。

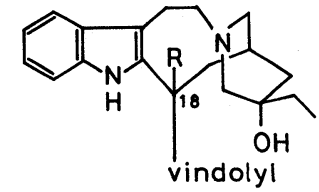

vinblastine $\left(\mathrm{R}=\mathrm{CO}_{2} \mathrm{Me}\right)$
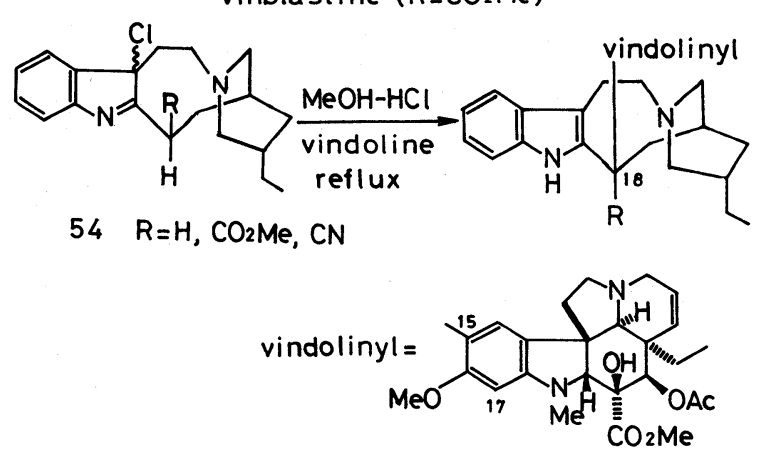

4.6. ベンゼン核に置換基の導入 3-クロロインド レニンに対して酢酸中 $\mathrm{Br}^{-}$をたは $\mathrm{SCN}^{-}$を反応させると ベンゼン核にブロモまたはチオシアナト基の置換したイ ンドールを与える ${ }^{20)}$ 。その結果を表 4 にまとめた。

この反応に対して次の二つの機構が考えられる。(path A ) $\mathrm{Br}^{-}$または $\mathrm{SCN}-$ が直接 5 位または 6 位に求核置換 する機構と，(path B) $\mathrm{Br}^{-}$まは $\mathrm{SCN}^{-}$が 3-クロロイ ンドレニンの塩素原子を攻撃することによって生成した $\mathrm{Br}^{+}$または $\mathrm{SCN}^{+} か ゙ ，$ 同時に生成するインドールに対し て親電子置換する機構である。
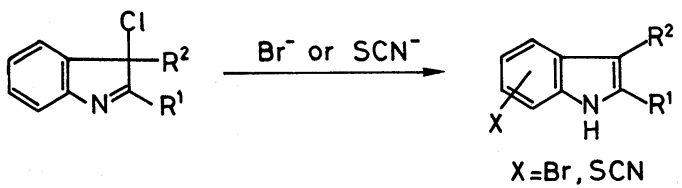

Table 4 'Formation of Bromo- and Thiocyanato-indoles

\begin{tabular}{l|l|l|l|c}
\hline \multicolumn{1}{c|}{$\mathrm{R}^{1}$} & $\mathrm{R}^{2}$ & Anion & \multicolumn{1}{c|}{ Product } & Yield(\%) \\
\hline $\mathrm{Ph}$ & $\mathrm{Me}$ & $\mathrm{Br}^{-}$ & 6-bromo- & quant. \\
$\mathrm{Ph}$ & $\mathrm{Me}$ & $\mathrm{SCN}^{-}$ & 6-thiocyanato- & quant. \\
$\mathrm{Ph}$ & $\mathrm{Ph}$ & $\mathrm{Br}^{-}$ & 6-bromo- & quant. \\
$\mathrm{Ph}$ & $\mathrm{Ph}$ & $\mathrm{SCN}^{-}$ & 6-thiocyanato- & quant. \\
$\mathrm{CO}_{2} \mathrm{Et}$ & $\mathrm{Me}$ & $\mathrm{Br}^{-}$ & 5-bromo- & 60 \\
\hline
\end{tabular}<smiles>[Y]c1ccc2c([R])c(-c3ccccc3)[nH]c2c1</smiles>

$N, N$-ジメチルアニリンの存在下同反応を行ならと $N$, $N$-ジメチルアニリンの p-ブロム体打よび p-チオシアナ 卜体と 2,3-ジフェニルインドールが高收率で生成するこ と,さらにブロモ拉よびチオシアナトインドールの置換 位置が 2,3-ジ置換インドールを直接臭素によってブロム 化した時あるいはチオシアノーゲンによってチオシアナ 卜化した時 ${ }^{35)}$ の置換位置とよく対応していることから 親電子置換反応の機構 (path B)の方が妥当だと考えて いる。参考までに 2,3-ジ置換インドールを直接臭素化し た時のブロムの置換位置を表 5 亿まとめる ${ }^{36)}$ 。一般則を 導き出すには反応例が十分ではないかもしれないが臭素 化がインドールの 5 位に起るか 6 位に起るかは 2 位の置 換基が最も重要な鍵を握っているようで, 電子吸引性 基か電子供与性基かによってそれぞれ 5 位または 6 位で 起る。表 5 の結果をみると 3 位の置換基の電気的な性質 はそれ程重要とは思われない。

一方, 日野ら ${ }^{8)}$ は3-ブロモインドレニン 55 のブロム が熱的にか，または酸触媒反応によってべンゼン核に入 ることを報告している。この反応の機構の詳細は明らか

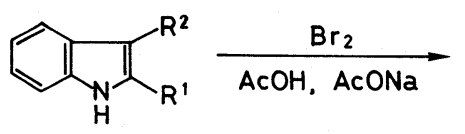<smiles>[R]c1[nH]c2cc(Br)ccc2c1[R]</smiles> 
Table 5 Bromination of 2,3-Disubstituted Indoles

\begin{tabular}{l|l|c|c}
\hline \multicolumn{1}{c|}{$\mathrm{R}^{1}$} & \multicolumn{1}{|c|}{$\mathrm{R}^{2}$} & $\begin{array}{c}\text { Position of } \\
\text { Bromination }\end{array}$ & Yield(\%) \\
\hline $\mathrm{Ph}$ & $\mathrm{Ph}$ & 6 & 90 \\
$\mathrm{Ph}$ & $\mathrm{Me}$ & 6 & 92 \\
$\mathrm{Ph}$ & $\mathrm{NO}_{2}$ & 6 & 59 \\
$\mathrm{Ph}$ & $\mathrm{COMe}$ & $6^{\mathrm{a})}$ & 78 \\
$\mathrm{Ph}$ & $\mathrm{CN}$ & 6 & 75 \\
$-\left(\mathrm{CH}_{2}\right)_{3}$ & $\mathrm{CO}-$ & 6 & 76 \\
$\mathrm{CO}_{2} \mathrm{Et}$ & $\mathrm{Me}$ & 6 & 69 \\
$\mathrm{CO}_{2} \mathrm{Me}$ & $\mathrm{CO}_{2} \mathrm{Me}$ & 5 & 92 \\
\hline
\end{tabular}

a) The originally assigned structure (5-bromo derivative)* was found to be incorrect $\left.{ }^{36}\right),\left[{ }^{*} \mathrm{G}, \mathrm{Buchmann}, \mathrm{D}\right.$. Rosner, J. Prakt. Chem., 22, 117 (1964)]

にされていないが，そのブロムの入った位置が上述の一 般則とよく対応しているところからこの反応も親電子的 に進行しているょうに思われる。<smiles>[R]C1=Nc2ccccc2C1([R])Br</smiles>

55<smiles>[R]c1[nH]c2ccccc2c1[R]</smiles>

3-ハロインドレニンのハロゲンは光照射によって転位 するが複雑な混合物を与える。八ロゲンは 4, 5, 6,7-位す べてに入り，その中でも 4-と7-位に多い $\left.{ }^{37}, 38\right)$ 恐らく ラジカル的に進行しているのであろう。<smiles>N#CC1=Nc2ccccc2C1(Cl)C=O</smiles><smiles>[Y6]c1ccc(-c2c(-c3ccccc3)[nH]c3cc([X])ccc23)cc1</smiles>
$X=\mathrm{Cl}, \mathrm{Br}$
4.7. 分子内閉環反応 3 位に求核体となるような 置換基をもつインドール，たとえばトリプトフォールや トリプタミン, トリプトファンなどの誘導体 56 にNBS や $t-\mathrm{BuOCl}$ を反応させると中間にハロインドレニンが 単離されることなく直接閉環体を与える。

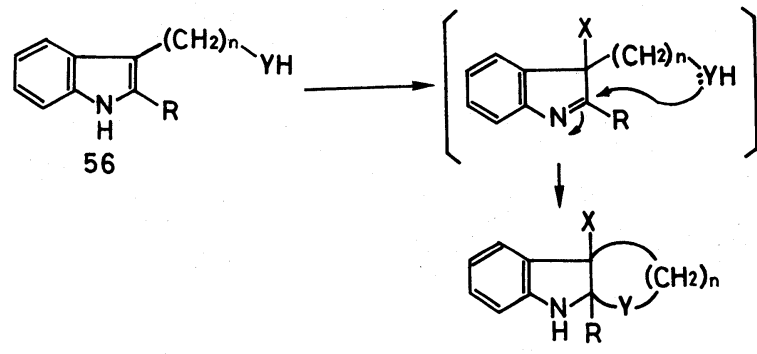

2 位に置換基がない場合には脱ハロゲン化水素して芳 香化する ${ }^{39,21)}$ 。トリプトフオール $(57, \mathrm{Y}=\mathrm{O}, \mathrm{n}=2)$ と NBS または NCSの反応では複雑な混合物を与える ${ }^{21)}$ 。

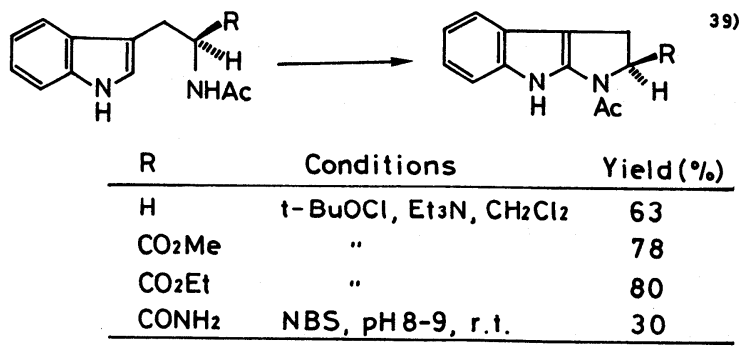

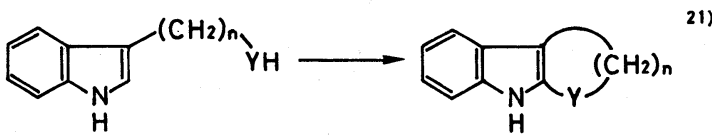

57

\begin{tabular}{lllc} 
YH & $n$ & Conditions & Yield $(\%)$ \\
\hline $\mathrm{NMe2}$ & 2 & $\mathrm{NBS}, \mathrm{CCl}_{4}, \mathrm{r} . \mathrm{t}$. & $65^{\mathrm{a}}$ \\
$\mathrm{OH}$ & 3 & $\mathrm{NBS}, \mathrm{CH}_{2} \mathrm{Cl} 2,-15--17^{\circ}$ & $57^{\circ}$
\end{tabular}

a) Obtained as a quarternary salt $\left(Y=\mathrm{N}^{+} \mathrm{Me}, \mathrm{Br} \mathrm{r}^{*}\right)$.

b) Accompanied by the formation of 3-(3hydroxypropyl)oxindole $(9 \%)$.

Table 6 Formation of Bromoindoles from 3-Bromoindolenines 55

\begin{tabular}{l|l|l|c|c|c}
\hline \multicolumn{1}{c|}{$\mathrm{R}^{1}$} & $\mathrm{R}^{2}$ & \multicolumn{1}{|c|}{ Conditions } & $\begin{array}{c}\text { Position of } \\
\text { Bromination }\end{array}$ & Yield (\%) & Ref. \\
\hline $\mathrm{SEt}$ & $\mathrm{Ph}$ & EtOH-HCl & 6 & 56 & 8 \\
$\mathrm{SEt}$ & $\mathrm{Ph}$ & $\mathrm{CCl}_{4}$, reflux & 6 & 92 & 89 \\
$\mathrm{SO}_{2} \mathrm{Et}$ & $\mathrm{Ph}$ & $\mathrm{CCl}_{4}$, reflux & 5 & $87(6: 1)$ & 8 \\
$\mathrm{Br}$ & $\mathrm{Ph}$ & $\mathrm{AcOH}$, r.t. & $6+5$ & quant. & 38 \\
$\mathrm{Ph}$ & $\mathrm{Ph}$ & $\mathrm{Cl}_{2} \mathrm{CHCHCl}$, reflux & 6 & quant. & 38 \\
$\mathrm{Ph}$ & $\mathrm{Ph}$ & $\mathrm{AcOH}$, r.t. & 6 & &
\end{tabular}


YがSの場合には八ロゲン化剤がイオウ原子を攻撃し， $\mathrm{n}=2$ ではジスルフィド $58, \mathrm{n}=3$ では図に示したよ らな機構で三環性化合物 59 が得られている ${ }^{21}$ 。<smiles>CCCc1c[nH]c2ccccc12</smiles>

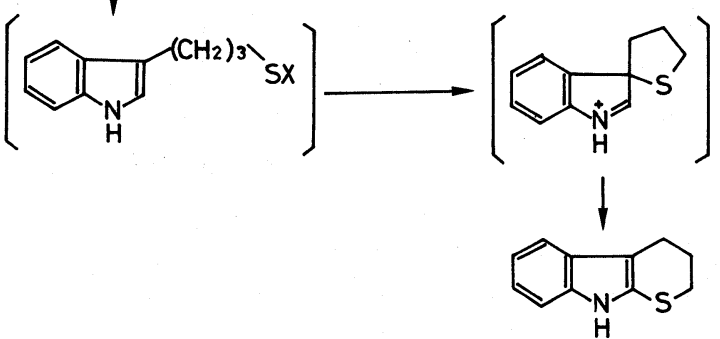

59

$2-$ ×ルトリプトフオール 60 に $t-\mathrm{BuOCl}$ を反応さ せると 61 が単離でき，これにアジ化ナトリウムを反応 させると 62 を生成する ${ }^{40}$ )。この化合物は 60 亿直接ア ジ化ヨウ素を反応させても得られる99。62 は酢酸中で 䚓汼すると環開裂, 二重結合の異性化, [3,3] シグマト ロピー転位を起こして2-アジドメチル体 63 に転位する。 一方，Nb-アセチル-2-メチルトリプタミン 64 にアジ化ヨ ウ素を反応させると 65 と 66 がそれぞれ $48,19 \%$ の 収率で得られる。66 は酢酸中安定であるので 66 は65 とは独立に生成したものと考えられる ${ }^{40}$ 。

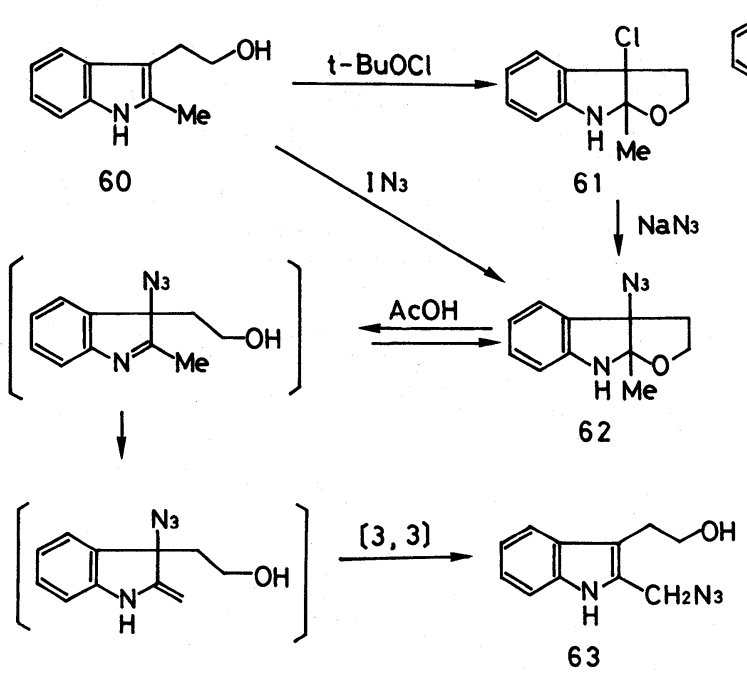

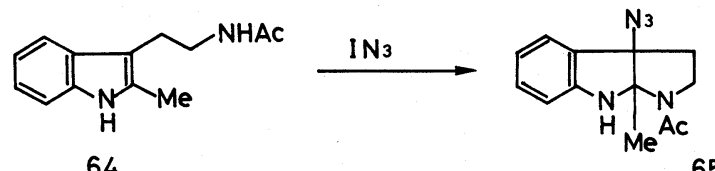

65<smiles></smiles>

66

もう一つの閉環の仕方として次の図に示すように二重 結合の移動後 2 位アルキル基に開環する可能性がある。 たとえば 67 を酰酸中酶酸ナトリウムを反応させると 68 が得られ，これに $\mathrm{CN}^{-}$を応させると 69 を与える ${ }^{41}$ 。 また， 70 に $t$ - $\mathrm{BuOCl}$ を反応させると 72 と 73 が得ら れる。この反応は恐らく上の例と同じょうに閉環体 71 ができ, 72 や 73 は71 の二次成績体として説明され る $^{19)}$ 。

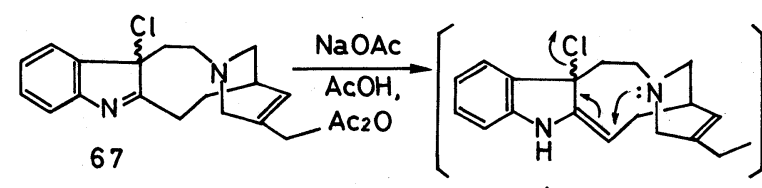

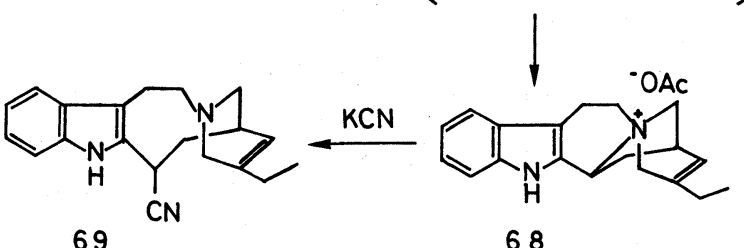

69 68

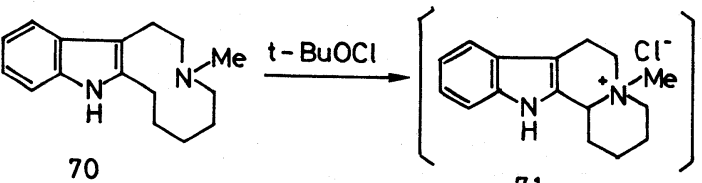

71<smiles>CN1CCCCC1C1(Cl)c2ccccc2N=C2C3=CCCCN3CC21Cl</smiles>
73

72

4.8. インドールの再生一ハロゲン化剂としての反応 3-ハロインドレニンはすでに述べたように（4.4.) I-, ホスフィン，チオールなどの求核剤と反応させるとそれ ぞれヨウ素，ホスフィンオキシド，ジスルフィドを生成 すると同時にインドールを再生する ${ }^{20) 。 ~}$

3-ブロモインドレニンはスカトールのように活性な化 


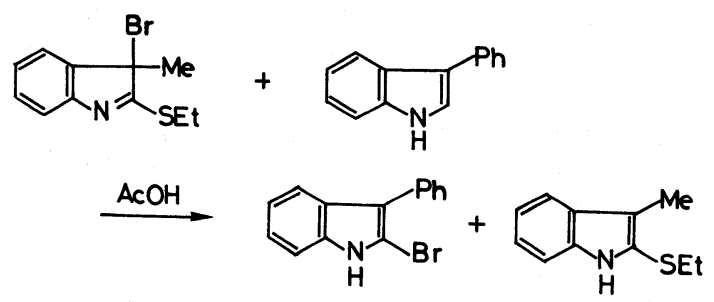

合物をブロム化することが知られている。これらはいず れもハロインドレニンのハロゲンが形式的にハロニウム イオン $\left(\mathrm{X}^{+}\right)$として反応している例である ${ }^{8)}$ 。

\section{5.おわりに}

以上述べたように3-ハロインドレニンは不思議な化合 物でまだまだ不明な点が多いけれども，それがまたこの 化合物の魅力にもなっている。ここには述べなかったけ れども 3-オキシ，3-アセトキシ，3-アジド，3-ニトロインドレニンなどもそれぞれ一味違った反応性を示す。 併せて今後の展開を期待したい。

(昭和 54 年 2 月 27 日受理)

\section{文献}

1) W.O. Godtfredsen, S. Vangedal, Acta Chem. Scand., 10, 1414 (1956)

2) J.C. Powers, "The Chemistry of Heterocyclic Compounds" W.J. Houlihan Ed., vol. 25, p.127 (1972) John Wiley

3) N. Finch, W.I. Taylor, J. Am. Chem. Soc., 84, 1318 (1962) ; ibido, 84, 3871 (1962)

4) P.G. Gassman, G.A. Campbell, G. Mehta, Tetrahedron, 28, 2749 (1972)

5) K.V.Lichman, J. Chem. Soc. C, 1971, 2539

6) J.P. Kutney, J. Beck, F. Bylsma, J. Cook, W. J. Cretney, K. Fuji, R. Imhof, A.M. Treasurywala, Helv. Chim. Acta, 58, 1690 (1975)

7) G.S. Omenn, A. Fontana, C.B. Anfinsen, J. Biol. Chem., 245, 1895 (1970)

8) T. Hino, M. Endo, M. Tonozuka, Y.Hashimoto, M. Nakagawa, Heterocycles, 2, 565 (1974) ; Chem. Pharm. Bull. (Tokyo), 25, 2350(1977)

9) M. Ikeda, F. Tabusa, Y. Nishimura, S. Kwon, Y. Tamura, Tetrahedron Lett., 1976, 2347

10) M.De Rosa, J. Chem. Soc. Chem. Commun., 1975, 482 ; J. Org. Chem., 43, 2639 (1978)

11) L.J. Dolby, G.W. Gribble, J. Org. Chem., 32, 1391 (1967)

12) R.J. Owellen, J. Org. Chem., 39, 69 (1974)

13) F.M.Hershenson, K.A. Prodan, R.L. Kochman, J.L. Bloss, C.R. Mackerer, J. Med. Chem., 20, 1448 (1977)

14) E. Wenkert, J.S. Bindra, C-J. Chang, D.W.Co- chran, D.E. Rearick, J. Org. Chem., 39, 1662 (1974)

15) J.-Y. Laronze, J. Laronze, D. Royer, J. Lévy, J. Le Men, Bull. Soc. Chim. France., 1977, 1215

16) M.E. Kuehne, R. Hafter, J. Org. Chem., 43, 3702 (1978)

17) M.E. Kuehne, D.M. Roland, R. Hafter, J. Org. Chem., 43, 3705 (1978)

18) H.Zinnes, J.Shavel, Jr., J. Am. Chem. Soc., 84, 1320 (1962) ; J. Org. Chem., 31, 1765 (1966)

19) A.J. Gaskell, H. -E. Radunz, E. Winterfeldt, Tetrahedron, 26, 5353 (1970)

20) Y. Tamura, M.W. Chun, H. Nishida, M. Ikeda, Heterocycles, 8, 313 (1977)

21) T.Hino, H. Miura, T. Nakamura, R. Murata, M. Nakagawa, Heterocycles 3, 805 (1975); Chem. Pharm. Bull., (Tokyo), 26, 3695(1978)

22) A. Walser, J.F. Blount, R.I. Fryer, J. Org. Chem., 38, 3077 (1973)

23) J.-Y. Laronze, J. Laronze, J.Lévy, J. Le Men, Tetrahedron Lett., 1974, 491

24) T. - L. Ho, "Hard and Soft Acids and Bases Principle in Organic Chemistry", (1977) Academic Press

25) Y. Tamura, M.W. Chun, H. Nishida, S. Kwon, M. Ikeda, Chem. Pharm. Bull. (Tokyo), 26, 2866 (1978)

26) W.I. Taylor, Proc. Chem. Soc., 1962, 247

27) R. J. Owellen, C.A. Hartke, J. Org. Chem., 41, 102 (1976)

28) Y. Tamura, M.W. Chun, K. Ohno, S. Kwon, M.Ikeda, Chem. Pharm. Bull. (Tokyo), 26, 2874 (1978)

29) N. Aimi, Y. Asada, S. Tsuge, T. Kohmoto, K. Mogi, S. Sakai, Heterocycles 5, 267 (1976)

30) G. Buchi, R.E. Manning, J. Am. Chem. Soc., 88, 2532 (1966)

31）坂井進一郎, 久保陽徳, 片野清昭, 新間信夫, 笹 子久美子, 薬誌, 93，1165 (1973)

32）坂井進一郎, 山中悦二, L.J. Dolby, 薬誌, 97, 309 (1977)

33) 坂井進一郎, 新間信夫, 薬誌, 98, 950 (1978)

34) N.Neuss, M. Gorman, N. Cone, L. L. Huckstep, Tetrahedron Lett., 1968, 783

34a) J.P. Kutney, J. Beck, F.B. Bysma, W.J. Cretney, J. Am. Chem. Soc., 90, 4504 (1968); J.P. Kutney, J. Cook, K. Fuji, A.M. Treasurywala, J. Clardy, J. Fayos, H. Wright, Heterocycles., 3, 205 (1975)

35) Y. Tamura, S.Kwon, M.W. Chun, M. Ikeda, J. Heterocyclic Chem., 15, 425 (1978)

36) Y. Tamura, H. Nishida, T. Uno, M. Ikeda, unpublished data. 
37）金子主税, 北村令子, 山本 敦, 藤井春恵, 染井 正徳, 第 10 回複素環化学討論会要旨集 p. 26 (1976)

38) Y. Tamura, H. Nishida, M. Ikeda, unpublished data

39) M. Ono, T.S.Stande, B. Witkop, J. Am. Chem. Soc., 90, 6521 (1968) ; 92, 343 (1970)
40) M Ikeda, K. Ohno, M. Katsura, M.W. Chun, Y. Tamura, J. Chem. Soc. Perkin I, in the press

41) J.P. Kutney, F. Bylsma, J. Am. Chem. Soc., 92, 6090 (1970) ; Helv. Chim. Acta., 58, 1672 (1975)

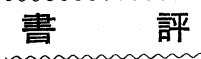

「有機化合物の構造決定法」

${ }^{13} \mathrm{C}-\mathrm{NMR},{ }^{1} \mathrm{H}-\mathrm{NMR}, \mathrm{IR}, \mathrm{MS}$ による総合解析

\author{
田中誠之編著 \\ 産業図書 発行 (1979) \\ 246 ページ； 4,000円
}

本書は Silverstein らの著書, “有機化合物のスペクト ルによる同定法”第 3 版, 東京化学同人, とほぼ同じ読 者層を対象にまとめられており，本自身の体裁もよく似 た印象をうける。著者らも述べているように，有機化合 物の構造決定にはなは等有効である ${ }^{13} \mathrm{C}-\mathrm{NMR}$ に中心 的手段としての位置を与えている点に本書の独自性があ り，本書の出版を時期を得たものとしている。科学者に とって, 特に有用と思われる点は, 多年にわたる著者ら の努力の成果である ${ }^{1} \mathrm{H}-$ および ${ }^{13} \mathrm{C}-\mathrm{NMR}$ の化学シフ 卜図表である。本書で初めて最新の機器分析法による構 造決定を学ぶ向きには, これらの表は極めて有用と思わ れる。

一方, 各分析法の原理に関しては, わずかのスペース しかさかれておらず，不充分に感じられた。この点は, 特に，FT 法による ${ }^{13} \mathrm{C}-\mathrm{NMR}$ スペクトルの解釈に, 当
って混乱を招くことになるだろう。実践的な解析力を養 成するのが本書の主目的とするならば，実際に読者が手 にする自分自身の試料についてのスペクトルに存在する “落し穴”について知る必要があろう。

演習問題は殆んどが平易であり, 科学者でも容易に構 造を数種にしぼり込むことができよう。本書ではシフト の加成則の有用性が強調されている反面, これらのもつ 不確実とについての注意が足りないようにも思える。こ れらの点は，むしろ個人の好みに多いによるのだが…。

ミスプリントがかなり目についた。その一っとして問 題 10 の ${ }^{13} \mathrm{C}-\mathrm{NMR}$ スペクトル中のシグナルの多重度に 誤りがあり，この問題を解く上で多少混乱した。しかし， いずれにせよ本書の有用性を大きく減ずるものではない。 良い演習, 参考書だと思う。

(M. K. )

○本会では会員のための欄が設けられておりますのでご利用下さい。!!

\section{会員の声}

\section{“こだま”欄について}

会員から開設の要望がありました会員の声欄を「こだ ま」という愛称名で第 34 巻から開設しています。

有機合成化学工業および技術に関連した興味ある話 題, 有機合成に関した海外事情の紹介, 本会に対する建 設的なご意見，ご提案等を歓迎します。

また会員相互の情報交換にもご利用下さい。

1. 原稿は 1 編 2 枚（本会規定の原稿用紙）以内を
原則とします。

2. 原稿には必らず氏名, 勤務先（または学校名）, 連絡先を明記して下さい。

（匿名希望の場合はその旨をお書き下さい。）

3. 原稿の採否決定は編集委員会にご一任願いま す。

4. 採用の原稿に対しましては規定の原稿料をお支 払いします。

5. 採否にかかわらす原稿は一切返却致しません。 会員諸氏は以上の要項に従って気軽にご利用下さい。 